\title{
Diskusi Tentang Peran Kearifan Lokal dalam Pemanfaatan Sumber Daya Laut dengan Kelompok Masyarakat Maluku Barat Daya
}

\author{
Posma Sariguna Johnson Kennedy ${ }^{1}$, Suzanna Josephine Tobing ${ }^{2}$, \\ Rutman Lumbantoruan ${ }^{3}$, Emma Tampubolon ${ }^{4}$ \\ Universitas Kristen Indonesia, Jakarta ${ }^{1,2,3,4}$ \\ posmahutasoit@gmail.com ${ }^{1}$
}

\begin{abstract}
The purpose of this study is to remind us that local wisdom must be maintained for a natural balance. Various activities were carried out to discuss the culture of the Sasi community in Southwest Maluku, through focus group discussions. In utilizing the natural resources of the community, Southwest Maluku still maintains the traditions, so that the sustainability of marine resources can be maintained between generations. Sea Sasi is a conventional system for the use of specific marine resources which is applied in a downward manner. In general, Sasi is a type of culture to determine the purpose of marine resources that can be taken, the time of opening may take, the location of utilization, and anyone who can use it, and sanctions if violating the rules. Sasi is an example of sustainable management that uses natural resources with community-based policies that are handed down from generation to generation. This culture is the application of community commitment to the protection of natural resources so as not to be disturbed or lost due to over-exploitation activities. But now there is an influence from globalization and greater economic motivation to forget the Sasi Culture. Therefore the Southwest Maluku Community needs to realize that this Sasi Culture must be preserved.
\end{abstract}

Keywords: Sasi Culture; Southwest Maluku; Fisheries; Marine Resources

\begin{abstract}
Abstrak
Tujuan dari studi ini adalah untuk mengingatkan kepada kita bahwa kearifan lokal harus dipertahankan untuk menjaga keseimbangan alam. Berbagai kegiatan dilakukan untuk membahas budaya masyarakat Sasi di Maluku Barat Daya (MBD), melalui diskusi kelompok terarah. Dalam memanfaatkan sumber daya alam masyarakat MBD masih mempertahankan tradisi tradisional, sehingga keberlanjutan sumber daya laut dapat dipertahankan antar generasi. Sasi Laut adalah sistem tradisional untuk penggunaan sumber daya laut (SDL) tertentu yang diterapkan secara turun menurun. Secara umum, Sasi adalah jenis budaya untuk menentukan pemanfaatan SDL yang bisa diambil, waktu pembukaan boleh mengambil, lokasi pemanfaatan, dan siapa saja yang bisa menggunakannya, serta sanksi jika melanggar aturan. Sasi adalah contoh manajemen berkelanjutan yang menggunakan sumber daya alam dengan kebijaksanaan berbasis masyarakat yang diturunkan dari generasi ke generasi. Budaya ini merupakan penerapan komitmen masyarakat terhadap perlindungan sumber daya alam agar tidak terganggu atau hilang karena kegiatan eksploitasi yang berlebihan. Akan tetapi saat ini terdapat pengaruh yang dari globalisasi
\end{abstract}


dan motivasi ekonomi yang lebih besar untuk melupakan Budaya Sasi. Oleh karena itu masyarakat MBD perlu menyadari bahwa Budaya Sasi ini harus dilestarikan.

Kata Kunci: Adat Sasi; Maluku Barat Daya; Perikanan; Sumber Daya Laut

\section{A. PENDAHULUAN}

Kabupaten Maluku Barat Daya (MBD) merupakan salah satu kabupaten di daerah kepulauan terselatan Indonesia. Wilayah MBD sangat strategis karena berada dekat dengan Negara Timor Leste serta Benua Australia. Daya tarik wisata yang paling dominan di MBD adalah wisata bahari yang terdiri dari pantai dan keindahan alam bawah laut (Kennedy, 2018).

Kabupaten MBD terletak di bagian paling selatan Segitiga Terumbu - yaitu wilayah 'jantung' keanekaragaman hayati laut dunia. MBD memiliki peran penting dalam melindungi ekosistem pesisir dan mendukung perekonomian perbatasan nasional. Secara umum, komoditas perikanan tangkap dan akuakultur di MBD memiliki nilai ekonomi dan nilai jual tinggi (Estradivari $d k k .$, 2015).

Masyarakat MBD kebanyakan hanya menggunakan tangkapan untuk konsumsi pribadi. Sebagian besar nelayan menggunakan modal pribadi dalam operasionalnya, sehingga tidak memiliki keterikatan dengan penjualan ikan hasil tangkapan. Sebagian besar transaksi penjualan ikan yang ditangkap dilakukan dengan transaksi tunai. Di beberapa desa, karena hasil tangkap ikan relatif sedikit, tidak jarang mereka menerapkan sistem barter, dimana hasil tangkapan ikan ditukar dengan barang kebutuhan dasar. Ikan-ikan yang tidak dijual dijual sebagai ikan segar biasanya dikeringkan dan diolah menjadi ikan asin. Ketika ikan asin telah dikumpulkan banyak, akan dijual ke ibukota kabupaten atau kecamatan atau pusat kerumunan lain, seperti di pelabuhan kapal dimana banyak kapal penumpang bersandar (Estradivari et.all, 2015).

Tempat untuk penjualan ikan masih sangat terbatas. Pemasaran hasil-hasil sumber daya perikanan masih dalam rantai perdagangan yang sederhana, bahkan sebagian besar nelayan langsung berhubungan dengan konsumen. Lebih banyak nelayan menjual ikannya kepada masyarakat untuk konsumsi langsung, sementara sisanya dijual kepada pedagang perantara (Estradivari $d k k ., 2015)$.

Tekanan terhadap sumber daya laut terus terjadi dan diperkirakan akan semakin meningkat seiring dengan pertumbuhan MBD sebagai kabupaten baru. Ketika banyak terumbu karang di wilayah lain terancam oleh berbagai aktivitas manusia, MBD masih dapat menjaga lingkungan pesisirnya. Potensi perikanan sangat besar di Provinsi Maluku dimana MBD menjadi bagian darinya. Oleh karena itu masih ada peluang dalam memperbesar jumlah produksi untuk perikanan (Estradivari $d k k$., 2015).

Ancaman terhadap sumber daya laut (SDL) dibagi menjadi dua kategori, yaitu ancaman secara langsung atau tidak langsung. Ancaman langsung umumnya berasal dari nelayan-nelayan luar wilayah yang sering datang dan mencuri dengan cara merusak. Mereka umumnya menggunakan bom ikan, potasium dan menyelam menggunakan kompresor. Pencurian sumber daya laut oleh nelayan luar ini terjadi di hampir semua wilayah MBD. Masyarakat secara aktif memantau dan mengusir nelayan yang mencuri di daerah ini, namun umumnya tidak terlalu banyak membuahkan hasil 
karena nelayan-nelayan ini datang dengan armada kapal yang lebih modern, dengan jumlah besar, dan datang pada saat nelayan tidak bisa melaut karena cuaca (Estradivari $d k k ., 2015)$.

Ancaman tidak langsung datang dari meningkatnya jumlah pembeli yang masuk di daerah untuk membeli hasil tangkapan ikan. Pembeli ini datang secara teratur, dan biasanya menentukan harga pasar dan komoditas yang cocok untuk dijual. Masyarakat menjadi penerima dengan posisi tawar rendah. Dengan penurunan harga ini, masyarakat tidak dapat melakukan apapun kecuali menerima, karena tidak ada pasar lain yang tersedia. Tidak adanya aturan khusus dan rendahnya pengawasan juga membuka celah bagi pembeli untuk melakukan transaksi. Saat ini, jumlah pembeli yang datang ke MBD sudah semakin beragam (Estradivari $d k k .$, 2015).

Tidak adanya pasar juga membuat orang memilih untuk menjual ke negara lain. Seperti halnya nelayan di daerah Wetar yang menjual ke Timor Leste, atau untuk pembeli dari lain negara dimana kapal asing masuk ke daerah perairan nasional untuk membeli ikan hidup secara langsung. Ini jelas menyebabkan kerugian ekonomi dan mengurangi devisa Indonesia. Pemerintah juga perlu meningkatkan fasilitas dan infrastruktur yang mendukung pengembangan perikanan, termasuk membangun fasilitas penyimpanan hasil tangkapan, memperhatikan rantai pemasaran, sehingga membuat lebih mudah bagi nelayan untuk memasarkan hasil tangkapan, serta mengurangi berbagai kegiatan penangkapan ikan illegal (Estradivari $d k k$., 2015).

Terlepas dari potensi ekologis, sosial, dan perikanan yang tinggi di Kabupaten MBD, tekanan/ancaman terhadap sumber daya laut dapat tinggi jika tidak dikelola dengan baik. Masyarakat saat ini dihadapkan dengan berbagai keterbatasan dalam pemanfaatan sumber daya laut, seperti tidak adanya fasilitas/infrastruktur penyimpanan dingin ikan hasil tangkapan, keterbatasan teknologi penangkapan (armada dan alat tangkap), kesulitan untuk mendapatkan bahan bakar, dan keterbatasan pemasaran untuk komoditas perikanan, budidaya dan perkebunan. Tidak adanya peraturan tentang pemanfaatan SDL dan sosialisasi serta informasi secara menyeluruh, menyebabkan masyarakat umumnya menerima dan mencoba apa pun yang diberikan oleh orang luar (Estradivari et.all, 2015).

Pengelolaan wilayah dan pengembangan sektor perikanan dengan prinsip keberlanjutan di Kabupaten MBD sangat penting untuk memastikan bahwa alam harus dipertahankan dan masyarakat terus mendapatkan manfaat dari sumber daya laut secara mencukupi. Pemerintah kabupaten dan provinsi, dengan bantuan dari pemerintah pusat dan mitra, perlu bekerja bersama dalam menentukan bentuk dan aturan, dan cara yang paling tepat dan efektif dalam pengelolaan SDL untuk MBD. Selain itu, pengawasan pemanfaatan SDL juga harus ditingkatkan (Estradivari $d k k ., 2015$ ).

\section{Solusi dan Target Luaran}

Berdasarkan paparan di atas, maka pelaksanaan pengabdian masyarakat ini dilakukan untuk mencari solusi agar sumber daya alam di MBD, khususnya perikanan, agar tidak habis karena pengelolaan yang tidak berkesinambungan. Dari berbagai literatur didapat salah satu yang dapat memperlambat habisnya sumber daya laut adalah kegiatan yang berasal kearifan lokal dari budaya MBD itu sendiri. Budaya Sasi merupakan warisan leluhur untuk menjaga kelestarian laut/perikanan di wilayah Maluku khususnya di MBD. 
Target luaran adalah meningkatkan pemahaman kembali diantara masyarakat MBD mengenai budaya Sasi agar tidak pudar ditelan perkembangan teknologi saat ini khususnya teknologi penangkapan ikan yang masif dengan menggunakan kapal-kapal besar.

\section{B. PELAKSANAAN DAN METODE}

Kegiatan ini dilakukan dengan metode diskusi kelompok terarah, bersama kelompok masyarakat MBD yang tinggal di Ambon. Karena adanya kesulitan menyatukan anggota diskusi, maka penulis dan tim mengundang untuk melakukannya secara terpisah sesuai kesempatan yang mereka miliki. Diskusi diakhiri dengan pembahasan juga dilaksanakan bersama Bupati MBD, Drs. Barnabas Nathaniel Orno.

\section{Lokasi dan Waktu}

Kegiatan dilakukan di Ambon, Maluku pada tanggal 8-12 November 2018.

\section{Peserta}

Diskusi dilakukan beberapa kali dengan berbagai kelompok, dimana satu kelompok bisa mencapai 4-10 orang, dengan total sekitar 25 orang. Rata-rata mereka berasal dari Maluku Barat Daya yang sudah menetap dan berkegiatan di Ambon. Mereka rata-rata sudah berpendidikan tinggi di tingkat sarjana S1 maupun S2, sehingga metode kegiatan yang paling cocok adalah diskusi kelompok terarah.

\section{Metode/Materi Kegiatan}

Metode kegiatan merupakan peningkatan pemahaman terhadap suatu masalah. Banyak topik diskusi yang dilakukan, salah satunya adalah mengenai sumber daya perikanan laut di MBD dan bagaimana kehidupan masyarakat MBD sehari-hari dalam memanfaatkan sumber daya tersebut.

\section{HASIL DAN PEMBAHASAN}

\section{Diskusi mengenai Adat Sasi di Maluku Barat Daya}

Masyarakat di MBD telah memiliki kearifan lokal dalam upaya untuk melestarikan sumber daya alam, yang disebut hukum adat sasi. Sasi laut merupakan sistem buka tutup tradisional untuk pemanfaatan SDL tertentu yang berlaku secara turun menurun. Umumnya mengatur jenis SDL yang boleh diambil, waktu buka tutup, lokasi pemanfaatan, dan siapa saja yang boleh memanfaatkan, serta sanksi apabila melanggar aturan.

Sasi di MBD lebih berbasis gereja, dimana pendeta dan kepala desa yang mengatur sasi. Sasi tidak berlaku untuk komoditas ikan atau hewan laut lainnya yang digunakan sebagai sumber protein harian bagi masyarakat. Sanksi bagi pelanggar sasi bersifat normatif (teguran dari pemimpin tradisional) dan nominal (sanksi dalam bentuk denda yang diatur oleh peraturan adat atau desa) (Estradivari $d k k ., 2015$ ).

Prinsip manajemen sasi didukung oleh hukum adat yang telah ada dari turuntemurun. Aturan itu ditegakkan karena masyarakat menganggap ketersediaan sumber daya alam, terutama di pulau-pulau kecil sangat terbatas, sementara itu kebutuhan masyarakat terus meningkat. Luasnya perairan Maluku membuat perikanan menjadi sektor utama yang memiliki peran penting sebagai pendorong utama pembangunan ekonomi di wilayah ini. Sampai saat ini melimpahnya sumber daya laut masih mampu dikelola, dijaga, dan dimanfaatkan dengan tepat (Persada, 2018).

Fungsi aturan adat tidak hanya agar masyarakat mematuhi hukum adat, tetapi mengajarkan bahwa setiap aktivitas manusia 
harus sesuai dengan daya dukung lingkungan. Dengan demikian aturan adat sasi memiliki sifat fungsi ekologi, fungsi sosial-ekonomi dan politik. Setiap lembaga adat memiliki sistem pemerintahan sendiri yang disiapkan oleh masyarakat. Aturanaturan ini mencakup struktur lembaga adat yang memiliki otoritas internal mengatur sasi (Fadlun, 2006).

Kata Sasi berasal dari kata "sanksi", yang berarti larangan. Larangan dalam penggunaan sumber daya alam (SDA) di darat dan laut dalam jangka waktu tertentu, yang ditujukan untuk kepentingan ekonomi masyarakat. Sasi juga dapat diartikan sebagai larangan untuk mengekstraksi dan merusak SDA tertentu dalam jangka waktu tertentu untuk keperluan melestarikan SDA (Persada, 2018).

Sasi memiliki aturan dan prosedur yang harus diterapkan, dengan melakukan peemanfaatan, pemeliharaan, dan pengawasan, agar keseimbangan lingkungan tetap terjaga, sehingga dapat dimanfaatkan oleh generasi berikutnya. Hukum adat ini mengajarkan bahwa manusia harus menjaga kelangsungan makhluk hidup lain yang dapat mengganggu keseimbangan alam. Sasi dapat memiliki nilai hukum, karena memiliki norma dan aturan yang berkaitan dengan cara, kebiasaan, perilaku yang mengandung unsur etika dan norma (Persada, 2018).

Sasi memiliki dampak positif untuk menjaga ketersediaan SDA agar tetap berkelanjutan. Jika adat sasi tidak ada, akan mengarah pada eksploitasi besar-besaran yang dapat mengganggu ketersediaan SDA. Sasi didirikan dengan tujuan agar masyarakat dapat mengelola produk kelautan dan perkebunan secara bijak, dan membagikan hasilnya secara adil sesuai dengan peraturan yang telah dibuat. Selain itu, tujuannya juga untuk menjaga keseimbangan antara alam, manusia dan dunia spiritual, karena mereka yang melanggar aturan sasi akan mendapat sanksi spiritual dan sanksi komunitas (Persada, 2018).

Sasi didasarkan pada pengetahuan masyarakat tentang waktu atau periode kapan suatu sumber daya dapat dipanen sehingga tidak mengganggu siklus hidupnya. Dengan demikian masyarakat mendapatkan hasil yang baik dan tercukupkan. Tujuan menggunakan adat sasi adalah bagaimana masyarakat menjadi bijak dalam mengambil dan mengelola produk laut (Persada, 2018).

Pelaksanaan Sasi diawasi dan dikoordinir oleh Lembaga Adat yang memiliki kewenangan dalam menetapkan suatu keputusan, yang disebut dengan Kerapatan Dewan Adat. Kepala pemerintahan negeri atau Raja adalah pimpinan lembaga adat atau biasa dikenal dengan ketua adat, bertugas untuk memimpin desa yang dibantu oleh saniri negeri dalam memberikan keputusan. Saniri negeri adalah lembaga adat di tingkat negeri atau kampung yang terdiri dari tokoh adat, tokoh agama dan perwakilan dari masing-masing soa (marga atau klan) (Persada, 2018).

Masing-masing kepala soa memiliki wilayah Soa, yang artinya "wilayah kekuasaannya terhadap terhadap sumber daya dusun tersebut." Dalam pelaksanaannya, terdapat dua istilah penting dalam sasi, yaitu Buka Sasi dan Tutup Sasi. Raja berwenang dalam menentukan kegiatan buka dan tutup sasi. Buka sasi adalah saat masyarakat diperbolehkan untuk memanen atau mengambil suatu sumber daya yang sedang di-sasi, sedangkan tutup Sasi adalah ketika sumber daya tersebut dilarang untuk dipanen, dan dilindungi kembali oleh hukum sasi. Sasi akan dibuka sesuai waktu yang telah ditentukan dan dimulai dengan upacara adat yang dihadiri oleh unsur-unsur adat, para saniri negeri serta masyarakat desa (Etlegar, 2013). 


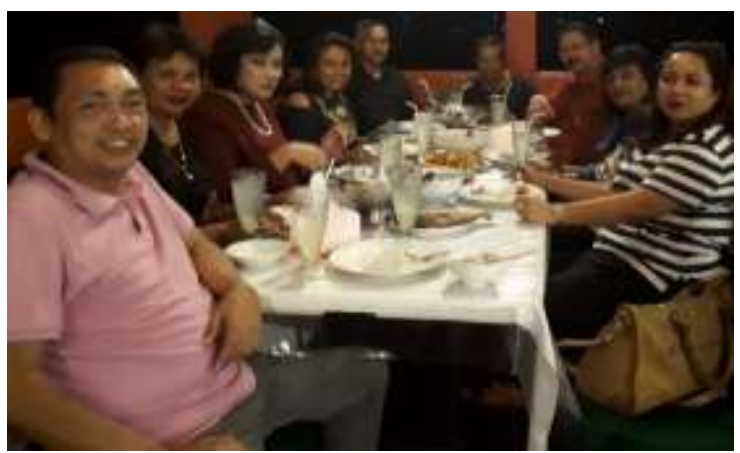

Gambar 1. Diskusi Bersama Masyarakat MBD di Ambon, Lokasi Pantai Lateri

Pembukaan Sasi laut dilakukan berdasarkan dua alasan, yaitu pertama adanya permintaan pasar atau pembeli yang ditujukan untuk kebutuhan ekonomi. Kedua, untuk kebutuhan konsumsi masyarakat sehari-hari dan keperluan sosial masyarakat, seperti pembangunan atau perbaikan masjid atau gereja, fasilitas-fasilitas desa dan perayaan hari-hari besar keagamaan (Persada, 2018).

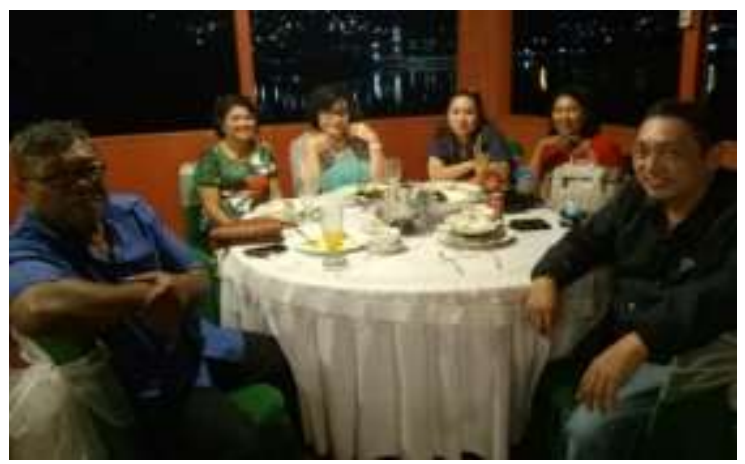

Gambar 2. Diskusi Bersama Masyarakat MBD di Ambon, Lokasi Pantai Lateri

Rata-rata pembukaan Sasi dilakukan setiap satu sampai tiga tahun sekali, umumnya dilakukan setelah ada pembeli dari luar datang dan melakukan penawaran. Di pulau-pulau sebelah barat (dari Wetar hingga Sermata), pembeli yang datang kebanyakan adalah orang-orang dari Sulawesi Selatan. Sementara, di pulau-pulau sekitar Babar, pembeli yang datang adalah pedagang- pedagang keturunan Tiongkok dari Tepa, Saumlaki, dan Tual (Estradivari $d k k ., 2015$ ).

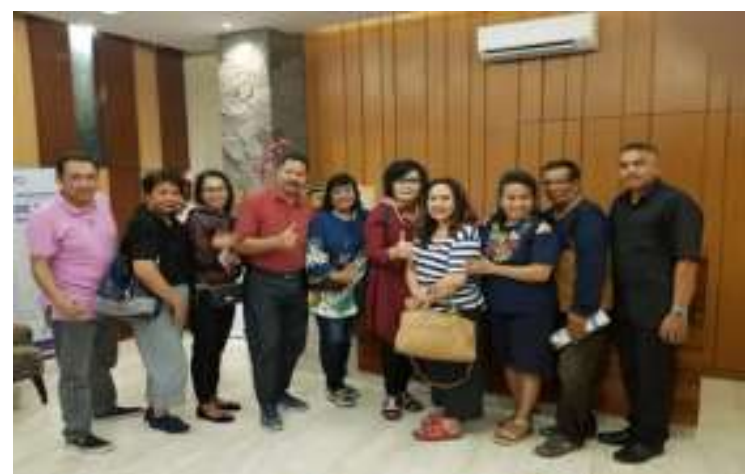

Gambar 3. Foto Bersama setelah Melakukan Diskusi di Pantai Lateri, Ambon

\section{Faktor-Faktor Pendorong Kegiatan}

Implementasi aturan Sasi di berbagai daerah memberikan peluang bagi makhluk hidup laut untuk berkembang, menjaga kualitas dan kuantitas populasi, sehingga orang dapat menggunakan sumber daya ini secara berkecukupan. Oleh karena itu keberadaan sasi sangat membantu masyarakat dalam mengelola dan memelihara SDA. Selain itu ada nilai-nilai budaya yang terus dianut, menerapkan hukum yang harus dipenuhi dari satu generasi ke generasi berikutnya (Pattinama dan Patipelony, 2003).

Sasi merupakan contoh manajemen dalam pemanfaatan SDA secara berkelanjutan oleh masyarakat berdasarkan kearifan lokal yang diturnnkan dari generasi ke generasi. Penerapan sasi ini merupakan bukti komitmen masyarakat untuk menjaga SDA di laut dan di darat sehingga tidak terganggu atau hilang karena kegiatan eksploitasi yang berlebihan. Dengan aturan ini, jumlah dan waktu pengambilan atau panen sumber daya diatur untuk dapat dimanfaatkan oleh masyarakat, dan juga menjaga ketersediaan sumber daya secara berkelanjutan (Persada, 2018).

Dalam Sasi laut, sumber daya merupakan milik bersama (communal 
property resources), sedangkan sasi darat cenderung milik pribadi. Dalam sasi laut, seluruh aspeknya dikelola bersama-sama sehingga memiliki ikatan sosial budaya dan nilai norma-nonna yang relatif ketat. Dengan adanya ikatan sosial budaya dan normanorma atau hukum yang mengatur disertai dengan sanksi yang telah disepakati bersama, maka tidak sembarang orang dan waktu untuk mengambil atau memanen SDA yang ada di lautan. Hal ini memberikan pengaruh yang cukup besar karena dapat menjaga SDA dan lingkungan. Selain itu, alat yang diperbolehkan dalam memanen saat sasi dibuka tidak boleh merusak alam yang ada. Aturan-aturan ini ditujukan untuk menghindari masalah yang ditimbulkan saat panen berlangsung, dan menghindari adanya gangguan siklus hidup sumber daya tersebut (Latuconsina, 2009).

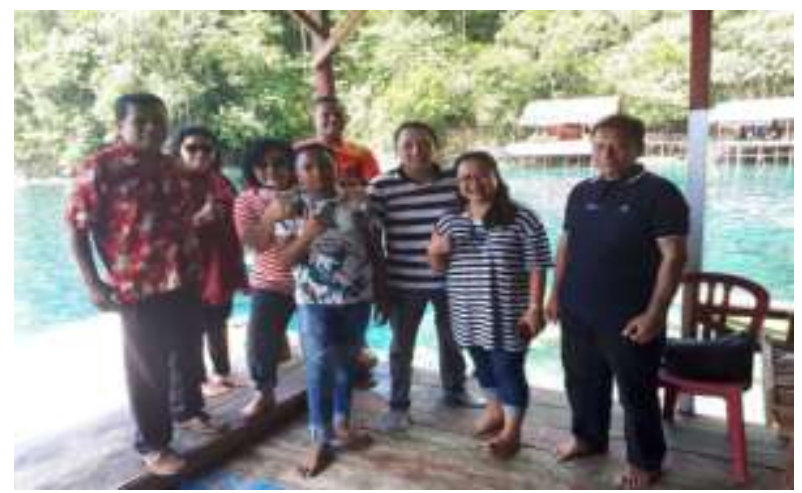

Gambar 4. Foto Bersama setelah Melakukan Diskusi di Pantai Lubang Buaya, Ambon
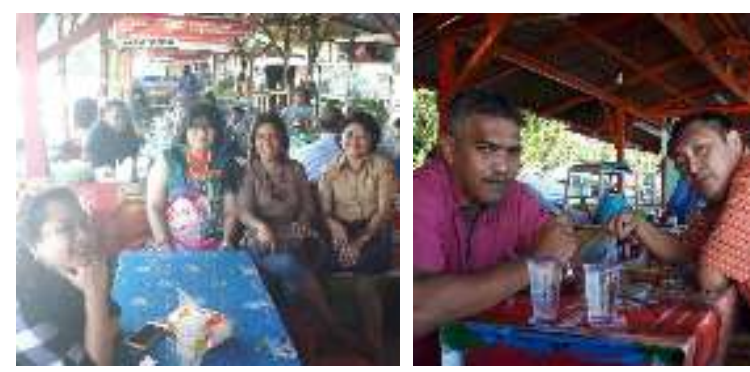

Gambar 5. Diskusi Bersama Masyarakat MBD di Pantai Natsepa, Ambon

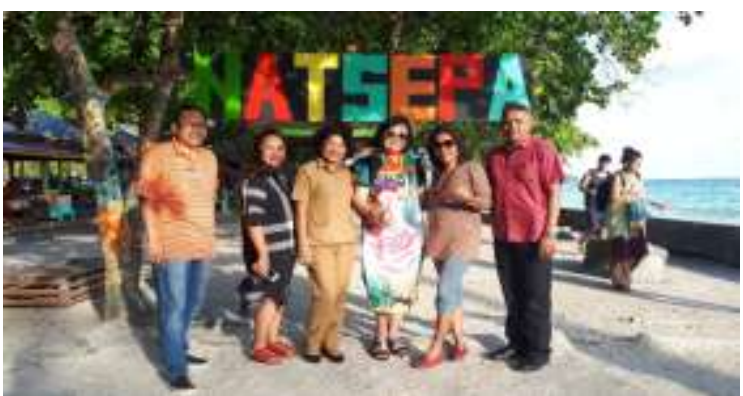

Gambar 6. Foto Bersama setelah Melakukan Diskusi di Pantai Natsepa, Ambon

\section{Faktor-Faktor Penghambat Keberlang- sungan Adat Sasi Saat Ini}

Dengan adanya kemajuan teknologi dan arus globalisasi, dikhawatirkan dapat menyebabkan semakin mengikis budaya dan identitas nasional. Hal ini juga dikhawatirkan dapat merusak aturan yang telah diterapkan oleh adat sasi, terutama terhadap kelangsungan SDA. Ancaman terutama adalah menurunnya kesadaran masyarakat tentang aturan yang telah ditetapkan. Pengaruh budaya dari luar daerah menyebabkan tingkat pemikiran masyarakat tentang tradisi sasi menjadi berkurang. Budaya eksternal akibat globalisasi membuat beberapa lapisan masyarakat, seperti generasi muda tidak lagi menganggap serius aturan hukuman adat yang merupakan ritual spiritual atau tradisional (Persada, 2018).

Terdapat faktor eksternal dan internal yang bisa mengubah sistem Sasi, terutama Sasi laut. Faktor eksternal adalah perkembangan teknologi yang sangat pesat dapat mempengaruhi masyarakat adat untuk meninggalkan teknologi penangkapan ikan tradisional. Faktor internal adalah kurangnya pengetahuan umum tentang siklus biologis kehidupan laut, khususnya yang disasi oleh hukum adat. Pergeseran telah terjadi pada saat ini, kini hasil atau pengelolaan diserahkan kepada pengusaha atau juru lelang, yang menyebabkan hilangnya hak individu masyarakat adat. Hal ini dapat memberikan fleksibilitas bagi 
pengusaha atau pelelangan untuk mengeksploitasi SDA tanpa memandang keberlanjutannya demi mengejar manfaat ekonomi (Persada, 2018).

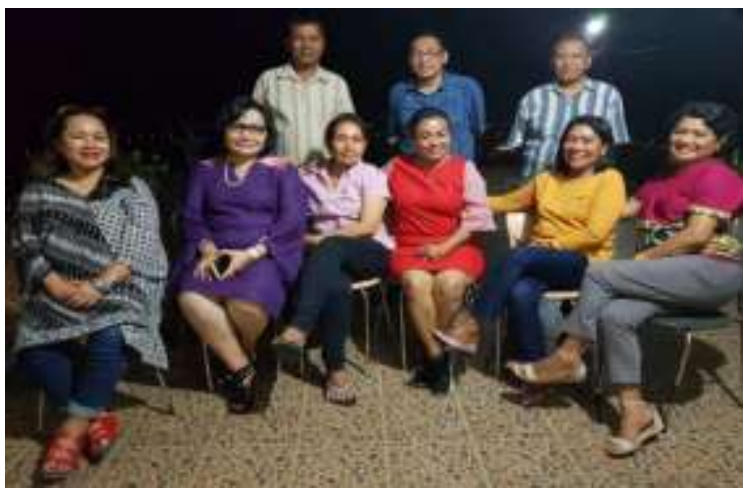

Gambar 7. Foto Bersama setelah Melakukan Diskusi di Salah Satu Rumah Peserta Diskusi, Ambon

Saat ini implementasi sasi telah dipengaruhi oleh ekonomi pasar, sehingga periode penutupan diperpendek, sedangkan periode terbuka diperpanjang, sehingga eksploitasi sumber daya dimaksimalkan. Sesuai prinsip ekonomi "mencapai laba maksimum dengan mengeluarkan modal seminimal mungkin" (Latuconsina, 2009).

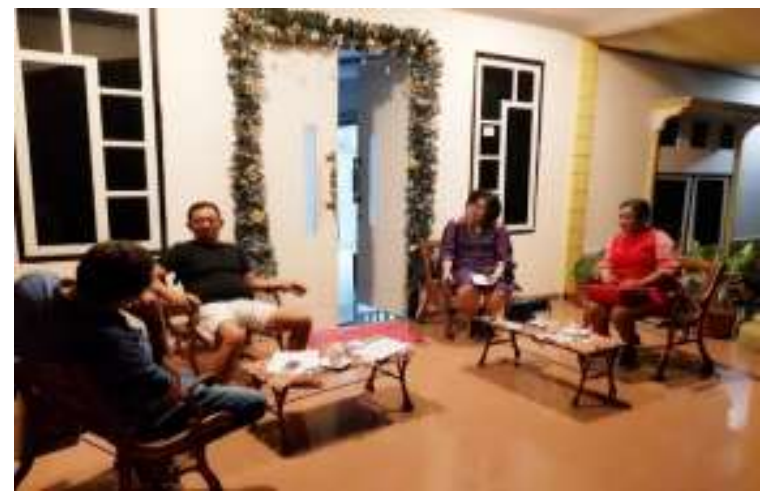

Gambar 8. Diskusi dengan Bupati MBD, Drs. Barnabas Nathaniel Orno

Sumber daya perikanan tidak akan dapat dipertahankan keberlanjutannya jika masyarakat mengubah orientasi laut sebagai bentuk perlindungan komunal menjadi pemenuhan kebutuhan yang sifatnya jangka pendek demi manfaat ekonomi yang lebih besar.

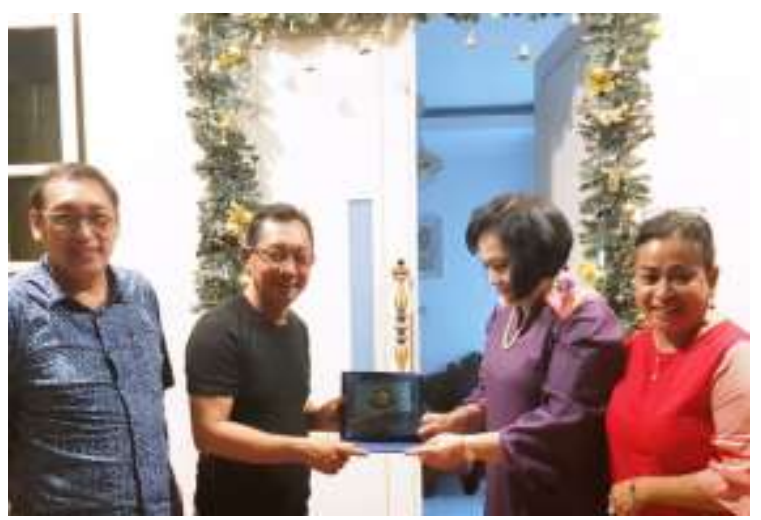

Gambar 9. Pemberian Plakat kepada Bupati MBD, Drs. Barnabas Nathaniel Orno sebagai Mitra dalam Penelitian dan Pengabdian kepada

Masyarakat dengan Universitas Kristen Indonesia

Kegiatan dapat dilakukan dengan baik, kelompok masyarakat MBD yang kami undang sangat antusias, dan banyak pencerahan didapat dari hasil diskusi ini. Diskusi mengenai Budaya Sasi meningkatkan kembali semangat untuk mempertahankannya. Kemajuan teknologi tidak ditolak namun harus diberlakukan secara natural tanpa menghilangkan kearifan lokal yang telah dimiliki sejak lama.

Dari hasil diskusi, saat ini ikan sudah kembali banyak di laut, bahkan sampai ke bibir pantai. Hal ini karena pengendalian penangkapan terhadap operasional kapalkapal besar dan program Kementerian Kelautan dan Perikanan terhadap penangkapan pencuri ikan yang dilakukan oleh-kapal-kapal ikan asing. Selain itu diharapkan dengan melestarikan Budaya Sasi ini perkembangan teknologi dapat diimbangi dengan penjagaan kelestarian laut melalui kelembagaan dan kearifan lokal.

Mulai ada ancaman terhadap keberlangsungan kearifan lokal ini, terutama menurunnya kesadaran masyarakat tentang aturan sasi, serta kurangnya perhatian dan koordinasi antara pemerintah daerah dan 
lembaga tradisional mengenai kelembagaan sasi.

Pemanfaatan terhadap sumber daya laut (SDL) harus terus dilakukan, yang diperkirakan akan semakin meningkat seiring dengan pertumbuhan MBD sebagai kabupaten baru. Perlindungan dan pengelolaan kawasan menjadi semakin penting, sehingga menjadi tuntutan yang harus dipenuhi dalam memenuhi kebutuhan ekonomi masyarakat serta melestarikan SDL bagi generasi selanjutnya

\section{PENUTUP}

\section{Simpulan}

Kearifan lokal sebagai bentuk dari strategi konservasi telah lama dilakukan masyarakat MBD sebagai upaya mempertahankan, melindungi dan melestarikan lingkungan dan sumber daya alam. Sasi merupakan bentuk kearifan lokal yang harus dipertahankan karena dapat melindungi wilayah dan kelangsungan sumber daya alamnya. Meskipun hampir semua masyarakat menggunakan SDL, mereka tetap berpartisipasi dalam melestarikannya dengan mempertahankan tradisi sasi dan mematuhi berbagai aturan yang telah ditetapkan.

\section{Saran}

Seluruh stakeholder, baik masyarakat maupun pemerintah perlu diingatkan kembali bahwa kearifan lokal tetap harus dipertahankan, agar kondisi lingkungan dan sumber daya alam tetap dalam kondisi seimbang. Seperti adanya budaya adat sasi di MBD yang bermanfaat secara keberlanjutan.

\section{Ucapan Terima Kasih}

Kami berterima kasih kepada Lembaga Penelitian dan Pengabdian kepada Masyarakat (LPPM UKI), Bupati MBD Drs. Barnabas Nathaniel Orno, dan segenap kelompok masyarakat MBD yang sudah bersedia melakukan berbagai diskusi.

\section{E. DAFTAR PUSTAKA}

Estradivari, Wisesa, N., Damora, A., Handayani, C., Amkieltiela, Wibowo, B., Hargiyatno, I.T., dan Miftakhul Huda, H.M. 2015. Menguak Potensi Ekologi, Sosial, dan Perikanan Maluku Barat Daya: Sebuah Temuan Awal, Marine Conservation Science, WWFIndonesia. Jakarta. Retrieved from www.wwf.or.id/xpdembd.

Etlegar, D. 2013. Peran Lembaga Sasi Tradisional dalam Pengelolaan Dusun di Negara Allang, Kecamatan Leihitu Barat, Kabupaten Tengah. Departemen Pengelolaan Hutan. Institut Pertanian Bogor, Bogor.

Fadlun, A.A. 2006. Yurisdiksi Sasi sebagai Model Kontra Sumber Daya Alam Berbasis Masyarakat di Maluku Tengah. Thesis Program Hukum Pemerintah Daerah Kepulauan. Program Studi Hukum. Universitas Sam Ratulangi, Manado.

Kennedy, P.S.J., Tobing, S.J., Heatubun, A.B., Lumbantoruan R. 2018. Potensi Pariwisata Maluku Barat Daya: Sebuah Kajian Pustaka, National Conference of Creative Industry, Sustainable Tourism Industry for Economic Development, Universitas Bunda Mulia, Jakarta, 5-6 September 2018.

Latuconsina, H. 2009. Eksistensi Sasi Laut dalam Pengelolaan Perikanan Berkelanjutan Berbasis Komunitas Lokal di Maluku. Jumal Manajemen 
Sumberdaya Perairan TRITON Vol. 5 (1): 63-71.

Pattinama, W., \& Pattipelohy, M. 2003. Upacara Sasi Ikan Lompa di Negeri Haruku. Kementrian Kebudayaan dan Pariwisata. Balai Kajian dan Nilai Tradisional, Ambon.

Persada, N.P.R., Mangunjaya, F.M., \& Tobing, I.S.L. 2018. Sasi sebagai Budaya Konservasi Sumber Daya Alam di Kepulauan Maluku, Jurnal dan Budaya Ilmu, Vol. 41, No.59, Juli 2018 . 